Periodica Polytechnica Architecture, 50(2), pp. 148-154, 2019

\title{
Organizational Culture and Stakeholder Success Criteria in Construction Projects
}

\author{
Ahmed Alhiddi ${ }^{1}$, Allan N. Osborne ${ }^{1 *}$, Kelechi T. Anyigor ${ }^{1}$ \\ 1 Department of Mechanical and Construction Engineering, University of Northumbria at Newcastle, \\ Newcastle-upon-Tyne NE1 8ST, UK \\ * Corresponding author, e-mail: allan.osborne@northumbria.ac.uk
}

Received: 19 June 2018, Accepted: 06 February 2019, Published online: 07 November 2019

\begin{abstract}
This paper presents the findings of a theoretical investigation into the association between organizational culture and stakeholder management. With an aspect focused on international construction projects, the study explores the relationship between the cultural origin of key stakeholders and the cultural context in which projects are realized. Emphasis is placed on the examination of project outcomes and the factors that influence cultural domain. Secondary data suggests stakeholder management and corporate culture are critical areas that decide an organization's success. The importance of these areas will inevitably grow in the future as projects continue to be procured in a global economy. Identifiable theoretical associations between the constructs have been found that provide early evidence that stakeholders and culture influence project life-cycles. Stakeholders—organizations and their representatives—must be informed of the distinct types of cultures and success criteria to ensure they manage them efficiently alongside traditional and longaccepted project variables.
\end{abstract}

Keywords

critical success factor, construction project, organizational culture, stakeholder management

\section{Introduction}

In recent years, construction project management has attracted enormous global interest, especially in organizational culture and stakeholder management. These two independent social constructs are crucial for successful construction project management; hence, the need to explore the relationship that exists between them.

In his often-cited textbook, Walker (2007) explains that construction project management (CPM) has been recognized as a distinct profession for a long time; yet, in the long-established context of natural and social scientific knowledge discovery, the study of how projects are organized and managed has, relatively speaking, evaded the attention of academics. Walker goes on to say, in a somewhat defiant manner, that, "management is the dynamic input that makes the organization work" (Walker, 2007). Aaltonen et al. (2008) sharpen the focus of Walker's viewpoint by explaining that the management of stakeholders' needs and requirements is an essential consideration for teams managing complex, global projects. More specifically from the perspective of the construction industry, several studies have pronounced that stakeholder involvement is an essential organizational component when realizing successful project outcomes (see Aaltonen et al., 2008; Meding et al., 2013; Walker, 2007.) Recognition that stakeholder management is a fundamental aspect with regard to construction project success has understandably grown in recent years (Yang et al., 2011).

Ankrah and Proverbs (2004) have acknowledged that organizational culture is an inherent aspect of a project's environment and that a definitive empirically-based interpretation of it is currently lacking. Eberlein (2008) expands this position by explaining that culture is a critical factor that contributes to the realization of successful project management outcomes. Because large projects typically involve many stakeholders, each with competing values and demands, Marrewijk and Smits (2016) have remarked they are potentially conflict-ridden environments. Driven by the need to gain a deeper, more meaningful understanding of organizational culture, Hofstede et al. (2002) present five dimensions that can be used for exploring culture 
awareness. They explained that managers could choose to use these dimensions to regulate the social conflict that may arise within a project environment.

Borders no longer limit construction and infrastructure projects: in fact, large-scale construction projects have increased the business opportunities available for global construction firms. These global construction projects involve managing culturally-diverse and globallydispersed teams, international financing, and more importantly, global stakeholders. Considering the above observations, the aim of this paper is to present the outcomes of a literature survey to find the association between organizational culture and stakeholder success criteria (see Fig. 1). This goal has resulted in the need to develop a conceptual, theoretical framework that illustrates the variables and steps that contribute to the management of successful construction projects in culturally-complex contexts.

\section{Project success}

According to the Oxford English Dictionary (Angus and Stevenson, 2010), success is defined as, "the accomplishment of an aim or purpose." Young (2010, p. 7) has defined success from managers' personal views as, "those words that conjure up a picture we paint in our minds" and he provided examples of these pictures: huge benefits gained, public recognition, great achievements, and promotion to new projects. This takes the point-of-view of the managers or leaders themselves. Müller and Turner (2007:p.299) defined success criteria for projects as, "the measures by which we judge the successful outcome of a project; these are dependent variables which measure project success." This introduces the concept that the project outcome is the measure of project success. Furthermore, the APM (2006:p.19) has defined success as, "the satisfaction of stakeholder needs, which is measured by the success

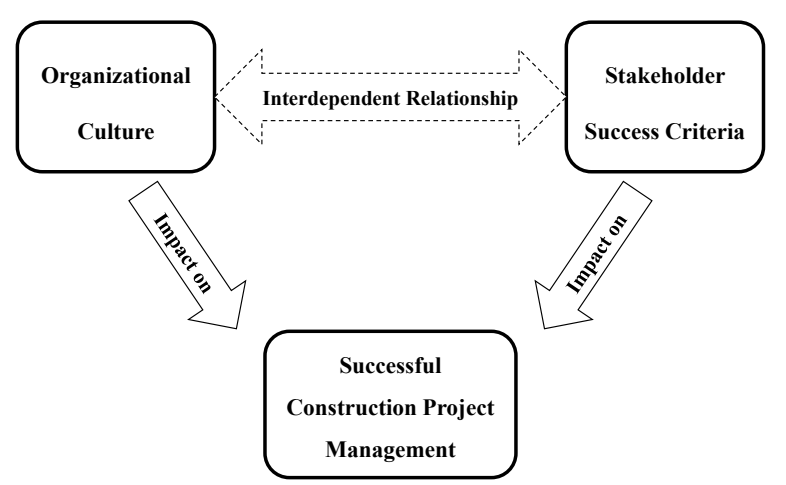

Fig. 1 Core elements of successful construction project management criteria as identified and agreed at the start of the project." The word success used in earlier definitions shows that it is dependent on some elements, like stakeholders, clients, sponsors, managers, resources, project team members, organizational culture. Moreover, each one of these elements can measure the success or failure of the project (Young, 2010).

In summary, the presented various authors' perspectives on project success definition agree that there must be some form of measure by which a project is judged to be either successful or not. The most common element in these definitions is the acknowledgement that projects have some level of complexity that involves different elements, including the two core elements-stakeholder management and organizational culture - which are the focus of this paper.

\section{Stakeholder management}

Stakeholder, as a lemma, first appeared in the domain of management literature in an internal memorandum at the Stanford Research Institute-now SRI International, Inc.-in 1963, where it was used to define ancillary support groups (Freeman, 2010:p.31). Aaltonen et al. (2008) discovered that for almost every publication about stakeholders that exists, a new definition is proclaimed. Of the many examples, a contemporary yet classic definition is offered by Friedman and Miles (2006:p.46) who have pronounced it as, "any group or individual who can affect or is affected by the achievement of the organization's objectives."

According to Friedman and Miles (2006), there are many publications that present different theories about stakeholders. For example, Phillips et al. (2003:p.480) have added that "one of stakeholder theory's greatest strengths is also one of its most prominent theoretical liabilities" and go on to define stakeholder theory as, "a theory of organizational management and ethics". In addition, Meding et al. (2013) have mentioned the importance of fully embracing stakeholder theories in construction projects due to the increase of stakeholders' diversity, power, and influence. However, Meding et al. (2013) appraise Smyth's (2008) work and discuss the utilitarian approach, which bases the value of a firm in terms of profit and growth. He suggested the need for ethics and relationship management principles to bridge the conceptual gap in this theory to help manage stakeholders in practice. In essence, studies mentioned in this paper have recognized stakeholders to have a considerable effect on project outcomes and acknowledge the need to manage this relationship with stakeholders successfully. This means considering some common factors such 
as stakeholders' characteristics and dynamics, relationship and communication with stakeholders, understanding engagement and needs, and defining the link between stakeholders and project success.

On the other hand, according to Rockart (1979:p.85), critical success factors (CSFs) "are, for any business, the limited number of areas in which results, if they are satisfactory, will ensure successful competitive performance for the organization." They are the few key areas where 'things must go right' for the business to flourish. If results in these areas are not adequate, the organization's efforts for the period will be less than desired." Likewise, Yang et al. (2014) have said that understanding stakeholders related factors are essential during the project process to establish appropriate decision-making strategies. These perspectives highlight the importance for managers to acknowledge CSFs. However, Jepsen and Eskerod (2009) found in their study that stakeholder identification, classification, and analysis are essential factors for stakeholder management. Olander and Landin (2008) recommended four CSFs for stakeholder management, which included analysis of stakeholders, communication, evaluation, and relationship.

So far, this paper has identified and discussed the fundamental theories explaining (1) stakeholder management and project success and (2) stakeholders' CSFs, both of which included consideration of the management of communication with stakeholders. Most of the factors discussed are essential to delivering successful projects. However, most of the authors have focused on finding the factors without ranking them or creating models to manage them.

Molwus (2014), in his doctoral thesis about stakeholder management in construction projects, has developed Yang et al.'s (2009) model that helps managers to identify and manage stakeholders CSFs. He ranked 15 CSFs according to priority by building a model for 5 main CSFs groups for the management of stakeholders in construction projects. Molwus's model not only named the 5 main stakeholder factors that have been highlighted in past studies but also substantiated the indicators for each factor; thus, making it easier for makers to apply the knowledge and manage stakeholders successfully (see Table 1). For these reasons, this paper uses these CSFs for stakeholder management in order to identify the CSFs of the selected project.

\section{Organizational culture}

Cameron and Freeman (1991) mentioned that the correct management of organizational culture leads to the delivery of successful projects. Their work directed scholars in the
Table 1 Critical success factors groups for stakeholder management (Molwus, 2014)

\begin{tabular}{|c|c|}
\hline Constructs & Indicators \\
\hline $\begin{array}{l}\text { Stakeholder } \\
\text { characteristics } \\
\text { and project } \\
\text { characteristics } \\
\text { (SCPC) }\end{array}$ & $\begin{array}{l}\text { - Clearly formulating the project mission; } \\
\text { - Ensuring the use of a favorable procurement } \\
\text { method; } \\
\text { - Carefully identifying and listing the project } \\
\text { stakeholders; } \\
\text { - Ensuring flexible project organization; and } \\
\text { - Identifying and understanding stakeholders' } \\
\text { areas of interests in the project. }\end{array}$ \\
\hline $\begin{array}{l}\text { Stakeholder } \\
\text { analysis (SA) }\end{array}$ & $\begin{array}{l}\text { - Determining and assessing the power (capacity } \\
\text { to influence the actions of other stakeholders); } \\
\text { urgency (degree to which stakeholders' claims } \\
\text { requires immediate attention); legitimacy } \\
\text { (perceived validity of claims); and proximity } \\
\text { (level of association or closeness with the } \\
\text { project) of stakeholders; } \\
\text { - Appropriately classifying stakeholders } \\
\text { according to their attributes/characteristics; } \\
\text { - Predicting and mapping stakeholders' behaviors } \\
\text { (supportive, opposition, neutral etc.); } \\
\text { - Predicting stakeholders' potential influence on } \\
\text { each other; } \\
\text { - Predicting stakeholders' potential influence on } \\
\text { the project; and } \\
\text { - Identifying and analyzing possible conflicts and } \\
\text { coalitions among stakeholders. }\end{array}$ \\
\hline $\begin{array}{l}\text { Stakeholder } \\
\text { dynamics (SD) }\end{array}$ & $\begin{array}{l}\text { - Resolving conflicts among stakeholders } \\
\text { effectively; } \\
\text { - Managing the change of stakeholders' interests; } \\
\text { - Managing the change of stakeholders' influence; } \\
\text { - Managing the change of relationship among } \\
\text { stakeholders; } \\
\text { - Managing change of stakeholders' attributes; } \\
\text { - Managing how project decisions affect } \\
\text { - stakeholders; and } \\
\text { implementing project decisions. }\end{array}$ \\
\hline $\begin{array}{l}\text { Stakeholder } \\
\text { engagement/ } \\
\text { empowerment } \\
\text { (SE) }\end{array}$ & $\begin{array}{l}\text { - Involving relevant stakeholders to redefine } \\
\text { (refine) project mission; } \\
\text { - Formulating appropriate strategies to manage/ } \\
\text { engage different stakeholders; } \\
\text { - Keeping and promoting positive relationships } \\
\text { among the stakeholders; } \\
\text { - Communicating with stakeholders properly and } \\
\text { frequently (instituting feedback mechanisms); } \\
\text { - Considering corporate social responsibilities } \\
\text { (paying attention to economic, legal, } \\
\text { environmental and ethical issues). }\end{array}$ \\
\hline $\begin{array}{l}\text { Project Success } \\
\text { (PS) }\end{array}$ & $\begin{array}{l}\text { - Completion of the project on time; } \\
\text { - Completion on budget; } \\
\text { - Completion to specified standards/qualities; and } \\
\text { - Completion to the satisfaction of a majority of } \\
\text { the project stakeholders. }\end{array}$ \\
\hline
\end{tabular}

management field to improve and develop different methods to help with the management of organizational culture. There has also been an abundance of research on organizational culture and its associated disciplines, which has resulted in many meanings and explanations of organizational culture 
and its relevance to other organizational parameters (Ankrah and Proverbs, 2004; Smircich, 1983; Zu et al., 2010).

One study was carried out by Schein (1985, p. 5), during which he defined organizational culture as "a pattern of basic assumptions, invented, discovered, or developed by a given group as it learns to cope with its problem of external adoption and internal integration that has worked well enough to be considered valid and therefore, to be taught to new members as the correct way to perceive, think, and feel in relation to those problems." According to Marcoulides and Heck (1993), organizational culture is a complex phenomenon characterized by many dimensions. One reason for the many dimensions that have been described is that organizational culture is very general and inclusive in scope (Cameron and Quinn, 2011). However, Hofstede et al. (2002) strongly argue that the cultural values of each organization need to be explicitly identified, and that reliance on reported values and beliefs from, for example, a parent company in one region may not be a reliable measure of the culture of a subsidiary in another region. This implies that changes in stakeholders, and their inherent cultures, will have an impact on the potential organizational culture of projects.

From the theoretical perspectives of organizational culture, Smircich (1983) mentioned that many scholars had linked the concept of culture with the study of organization management, but every organization theory had been studied from a different perspective in terms of the way it manages interdependencies and exchanges across system boundaries. For example, some scholars have studied organization and culture from a practical and operational perspective, while others have studied a rules or scripts perspective, and yet others have focused on one or more concepts of culture related to the organization, including cognitive, symbolic, structural, and psychodynamic perspectives.

Furthermore, many methods and frameworks have been designed to identify and measure organizational culture. In this context, Wallach (1983) developed a set of cultural dimensions based upon a synthesis of other major organizational culture indices. Another method is the Organizational Culture Profile Scale that was developed by O'Reilly et al. (1991). The third is the Competing Values Framework (CVF) that was developed by Quinn and Rohrbaugh (1983), and the fourth and final one is the Organizational Value Congruence Scale that was developed by Fitz-Enz (1986a; 1986b).

This paper focuses on CVF as a model to explain and recognize the differences between organizational culture types. Zu et al. (2010) have argued that the CVF developed by Quinn and his associates explores the deep structures of organizational culture relating to compliance, motives, leadership, decision-making, effectiveness, and organizational forms in the organization (Quinn and Rohrbaugh, 1983). Yeung et al. (1991) added that the CVF could be integrated into the organizational culture to other organizational components, which are both theoretically and psychometrically sound. Furthermore, CVF is built on two axes to explain the differences in value orientations. The axes are $(\mathrm{X}+\mathrm{Y})$ and are derived from the control-flexibility axis (vertical) reflecting the extent to which an organization focuses on change and stability. A focus on flexibility shows the organization's desire for flexibility and spontaneity, while a focus on control indicates a mutual desire to stay stable, controlled, and in order (see Fig. 2).

Ajmal and Koskinen (2008), however, mentioned that if managers understand the norms of organizational culture about the right and wrong and manage it correctly, it will lead to the successful operation of organizations. Likewise, Ashkanasy et al. (2000) have suggested that an awareness of culture types within the organization from the strategic phase of project life cycle is essential to recognize the project organization environment and beliefs that will reduce conflicts. Ankrah and Proverbs (2004) mentioned that organizational culture in construction projects consider the characteristics, tactics, competencies, goals, and values of the project environment. Therefore, recognizing the type of project organizational culture is essential to improve project delivery.

It has been observed that the earlier literature on organizational culture and project success shows a healthy relationship between these two elements. It revealed that identifying and understanding the types of culture within the

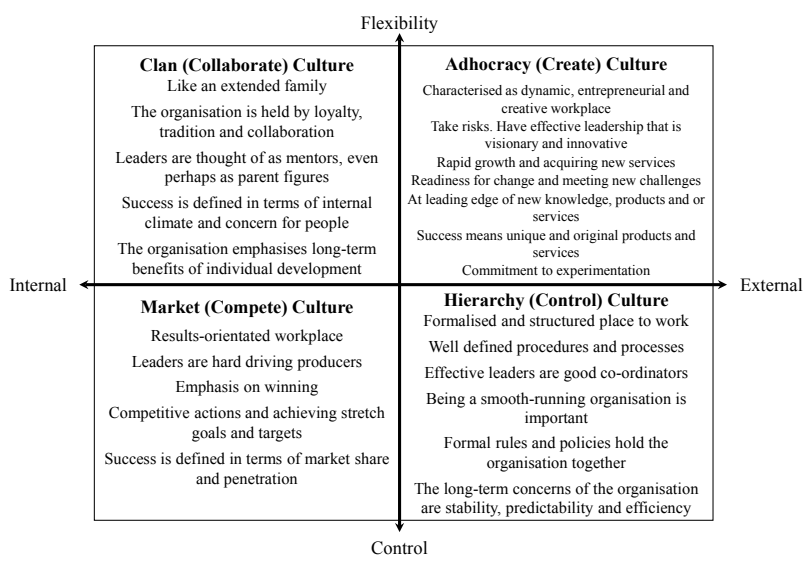

Fig. 2 Competing Values Framework (Cameron and Quinn, 2011) 
project reduces conflicts, promotes innovation that eventually leads to improved project delivery. It also defines the link between organizational culture and successful project management. Although the above-reviewed literature has defined the impact of organizational culture on project management success, as well as established the impact of stakeholder management on project management success, there is no apparent literature discussing the relationship between organizational culture and stakeholder management explicitly. If both organizational culture and stakeholder management impact the success or failure of project management, then it is logical to say that there must be some connection between the two. This study, therefore, intends to look at this undefined relationship with the aim of enhancing the tools currently available for improving construction project management.

\section{Research design}

The research procedure commenced with a review of the literature on stakeholder management and organizational culture to extract key theories. A construction project (as the subject of the case study) will be selected using the following criteria: service provider classified as a global provider for construction projects, the location of the project outside the home base of the service provider (another state, country, or region), and a construction project considered to be successful. Based on the literature survey, the research focus was set and a questionnaire structured for the collection of data using both the competitive value framework (CVF) instrument to identify the organizational culture of the chosen project and the stakeholder criteria for stakeholder management (Molwus, 2014; Yang et al., 2009) to identify the stakeholders' criteria of the chosen project. A web-based delivery method has been selected to administer the electronic survey questionnaire.

The target respondents of the survey questionnaire will be the decision makers of the selected project: managers, directors, operations managers, quality managers (both internal and external stakeholders related to construction projects), public and private clients, project professionals (in-house and external), and contractors and suppliers, as identified by Chinyio and Olomolaiye (2010). Furthermore, structural equation modelling (SEM) will be utilized to explore the associations between the constructs forming the two variables: organizational culture and stakeholder success criteria.

\section{Discussion}

The literature on stakeholder management shows the importance of recognizing and identifying the critical success factors to help managers deliver successful projects. Likewise, many scholars have mentioned the CSFs of stakeholder management within construction projects. Some have identified the CSFs' constructs (Chinyio and Olomolaiye, 2010; Jepsen and Eskerod, 2009), while others have identified the CSFs' indicators (Meding et al., 2013; Yang et al., 2009; Yang et al., 2014). Yang et al. (2009) investigated CSFs from both sides and ranked them from the most influential to the least. More recently, Molwus (2014) grouped the CSFs into five main constructs by converging the theories about stakeholder management and the outcomes arising from empirical studies.

Organizational culture theories link culture and organization projects to clarify the types of cultures in each organization. The organizational culture literature also shows how vital it is for managers to understand the types of culture in which a project is being delivered. Many theories that described culture have been presented in the literature (see Marcoulides and Heck, 1993; Schein, 1985; Smircich, 1983) and many authors have empirically examined these theories (see O'Reilly et al., 1991; Wallach, 1983). However, Cameron and Quinn's (2011) competitive value framework (CVF) has been used to underpin many types of research because it shows that it is both a theoretically and psychometrically sound instrument when integrating and operationalizing organizational culture with other organizational components (Cameron and Quinn, 2011; Yeung et al., 1991; Zu et al., 2010).

The initial examination has led to the hypothesis that the CSFs for stakeholder management in construction projects by Molwus (2014) has an association with organizational culture (see Fig. 3). Stakeholder characteristics and project characteristics (SCPC) indicators-ensuring flexible project organization and use of a favourable procurement method - can be linked with the CVF's adhocracy culture; while SCPC indicators, such as, formulating the project mission and identifying the project interest and stakeholders, are more likely associated with the CVF's hierarchy culture.

The stakeholder analysis (SA) indicator-determining and assessing the power, urgency, legitimacy, and proximity to stakeholders - shows an association exists with CVF's four culture types. The third construct, stakeholder dynamics (SD) as a whole, is more closely related 


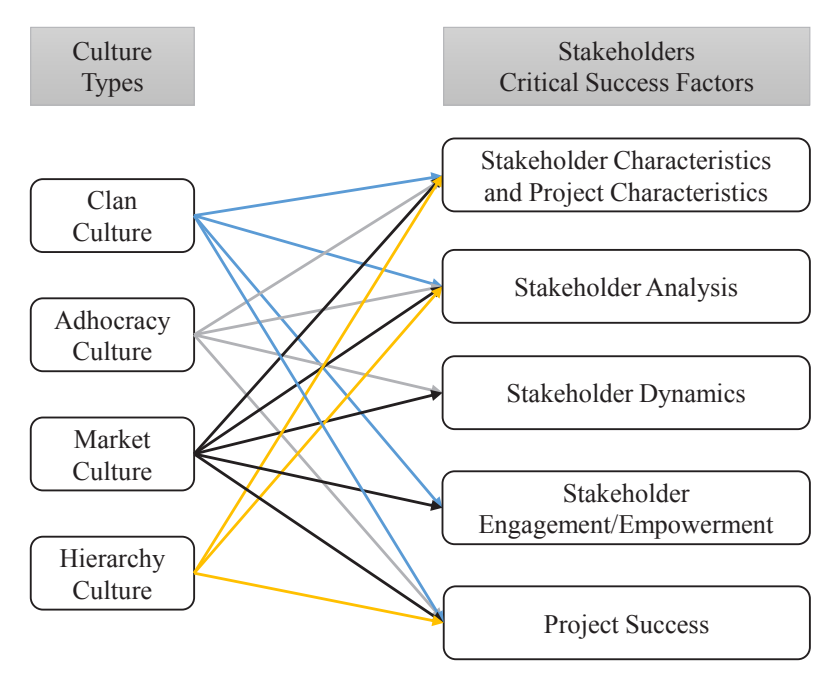

Fig. 3 Illustrated relationship between organizational culture and stakeholder CSF

to market and adhocracy cultures and, to a lesser degree, to clan culture. The construct for stakeholder engagement/ empowerment (SE), however, is more likely to be related to market and clan cultures. The last construct, project success (PS), shows a link with all the organization types.

\section{Conclusion}

The above indicative theoretical review shows that both stakeholder management and organizational culture have an impact on project success. To examine the relationship between organizational culture and stakeholder success criteria for a successful construction project, and to develop the indicators with the literary theories to classify the relationship between the two variants, it will be necessary to test Molwus's (2014) model (see Table 1) and Cameron and Quinn's (2011) CVF model (see Fig. 2).

\section{References}

Aaltonen, K., Jaakko, K., Tuomas, O. (2008) "Stakeholder salience in global projects", International Journal of Project Management, 26(5), pp. 509-516.

https://doi.org/10.1016/j.ijproman.2008.05.004

Ajmal, M. M., Koskinen, K. U. (2008) "Knowledge Transfer in ProjectBased Organizations: An Organizational Culture Perspective", Project Management Journal, 39(1), pp. 7-15.

https://doi.org/10.1002/pmj.20031

Angus, S., Stevenson, A. (2010) "Oxford dictionary of English", 3rd ed., Oxford University Press, Oxford, New York, Oxford, England.

Ankrah, N., Proverbs, D. (2004) "Treading the softer areas of construction management: a critical review of culture", In: 20th Annual ARCOM Conference, Heriot Watt University, Edinburgh, UK, pp. 551-558.

\begin{tabular}{|c|c|c|c|c|}
\hline $\begin{array}{l}\text { Determinants } \\
\text { of } \\
\text { Organisational } \\
\text { Culture }\end{array}$ & $\begin{array}{l}\text { Culture } \\
\text { Types }\end{array}$ & \begin{tabular}{|c|} 
Relationship between \\
Organisational Culture \\
$\&$ \\
Stakeholder \\
Management \\
\end{tabular} & $\begin{array}{l}\text { Stakeholder Critical } \\
\text { Success Factors }\end{array}$ & $\begin{array}{c}\text { Determinants } \\
\text { of } \\
\text { Stakeholder } \\
\text { Management }\end{array}$ \\
\hline $\begin{array}{c}\text { Identify } \\
\text { Organizational } \\
\text { Culture }\end{array}$ & $\begin{array}{c}\text { Clan } \\
\text { Adhocracy } \\
\text { Market } \\
\text { Hierarchy }\end{array}$ & $\begin{array}{c}\text { Test } \\
\& \\
\text { Evaluate }\end{array}$ & \begin{tabular}{|} 
Stakeholder Characteristics \\
\& Project Characteristics \\
Stakeholder Analysis \\
Stakeholder \\
Dynamics \\
Stakeholder Engagement/ \\
Empowerment \\
Project Success
\end{tabular} & $\begin{array}{c}\text { Identify } \\
\text { Critical Success } \\
\text { Factors for } \\
\text { Stakeholders }\end{array}$ \\
\hline
\end{tabular}

Fig. 4 Schematic conceptual framework

The discussion section of this paper evaluates some of the relationships between stakeholder management and organizational culture from various aspects, each of which requires empirical study to classify and identify the postulated relationships in terms of project success. Furthermore, the paper highlights the benefits of adopting the stakeholder management model in construction projects to achieve project success, as well as highlighting the importance of recognizing stakeholder success criteria. The paper goes on to explain the need to understand the types of organizational cultures within construction projects to sustain stakeholders and deliver the project outcome successfully.

It is proposed that a future investigation will analyse and empirically-investigate both theoretical models that were presented in the outline research design (as shown in Fig. 3) in order to derive a wealth of information about the relationship between the two core elements of construction projects in terms of success. From the empirically-derived results, the authors will investigate the findings with the aim of developing a framework that will explain the organizational culture and stakeholders' success criteria that determine successful construction projects (see Fig. 4).

APM (2006) "APM Body of Knowledge", 5th ed., Association for Project Management, High Wycombe, UK.

Ashkanasy, N. M., Wilderom, C., Peterson, M. F. (2000) "Handbook of organizational culture and climate", Sage Publications, London, UK.

Cameron, K. S., Freeman, S. J. (1991) "Cultural congruence, strength, and type: Relationships to effectiveness", Research in Organizational Change and Development, 5(1), pp. 23-58.

Cameron, K. S., Quinn, R. E. (2011) "Diagnosing and changing organizational culture based on the competing values framework", Jossey-Bass, San Francisco, CA, USA.

Chinyio, E., Olomolaiye, P. O. (2010) "Construction stakeholder management", Wiley-Blackwell, Chichester, West Sussex, UK 
Eberlein, M. (2008) "Culture as a critical success factor for successful global project management in multi-national IT service projects", Journal of Information Technology Management, 19(3), pp. 27-42.

Fitz-Enz, J. (1986a) "White-collar effectiveness: part 1: the employees side", Management Review, 75(5), p. 52.

Fitz-Enz, J. (1986b) "White-collar effectiveness: part 2: the organisation side", Management Review, 75(6), p. 52.

Freeman, R. E. (2010) "Strategic management: a stakeholder approach", Cambridge University Press, Cambridge, UK.

Friedman, A. L., Miles, S. (2006) "Stakeholders: theory and practice", Oxford University Press, Oxford, UK.

Hofstede, G. J., Pedersen, P., Hofstede, G. H. (2002) "Exploring culture: exercises, stories, and synthetic cultures", Intercultural Press, Yarmouth, Me, USA.

Jepsen, A. L., Eskerod, P. (2009) "Stakeholder analysis in projects: Challenges in using current guidelines in the real world", International Journal of Project Management, 27(4), pp. 335-343. https://doi.org/10.1016/j.ijproman.2008.04.002

Marcoulides, G. A., Heck, R. H. (1993) "Organizational Culture and Performance: Proposing and Testing a Model", Organization Science, 4(2), pp. 209-225 https://doi.org/10.1287/orsc.4.2.209

van Marrewijk, A., and Smits, K. (2016) "Cultural practices of governance in the Panama Canal Expansion Megaproject", International Journal of Project Management, 34(3), pp. 533-544. https://doi.org/10.1016/j.ijproman.2015.07.004

von Meding, J., McAllister, K., Oyedele, L., Kelly, K. (2013) "A framework for stakeholder management and corporate culture", Built Environment Project and Asset Management, 3(1), pp. 24-41. https://doi.org/10.1108/BEPAM-07-2012-0042

Molwus, J. J. (2014) "Stakeholder management in construction projects: a life cycle based framework", unpublished $\mathrm{PhD}$ thesis, HeriotWatt University, Edinburgh.

Müller, R., Turner, R. (2007) "The Influence of Project Managers on Project Success Criteria and Project Success by Type of Project", European Management Journal, 25(4), pp. 298-309. https://doi.org/10.1016/j.emj.2007.06.003

O'Reilly, C. A., Chatman, J., Caldwell, D. F. (1991) "People and Organizational Culture: A Profile Comparison Approach to Assessing Person-Organization Fit", Academy of Management Journal, 34(3), pp. 487-516. https://doi.org/10.5465/256404

Olander, S., Landin, A. (2008) "A comparative study of factors affecting the external stakeholder management process", Construction Management and Economics, 26(6), pp. 553-561 https://doi.org/10.1080/01446190701821810

Phillips, R., Freeman, R. E., and Wicks, A. C. (2003) "What Stakeholder Theory Is Not", Business Ethics Quarterly, 13(4), pp. 479-502.
Quinn, R. E., Rohrbaugh, J. (1983) "A Spatial Model of Effectiveness Criteria: Towards a Competing Values Approach to Organizational Analysis", Management Science, 29(3), pp. 363-377. https://doi.org/10.1287/mnsc.29.3.363

Rockart, J. F. (1979) "Chief executives define their own data needs", Harvard Business Review, 57(2), pp. 81-93.

Schein, E. H. (1985) "Organizational Culture and Leadership", 1st ed., Jossey-Bass Publisher, San Francisco, CA, USA.

Smircich, L. (1983) "Concepts of Culture and Organizational Analysis", Administrative Science Quarterly, 28(3), pp. 339-358. https://doi.org/10.2307/2392246

Smyth, H. (2008) "The credibility gap in stakeholder management: ethics and evidence of relationship management", Construction Management and Economics, 26(6), pp. 633-643. https://doi.org/10.1080/01446190801905414

Walker, A. (2007) "Project management in construction", 5th ed., Blackwell Publishing, Oxford, Malden, MA, USA.

Wallach, E. (1983) "Individuals and Organizations: The Cultural Match", Training and Development Journal, 37(2), pp. 28-36.

Yang, J., Shen, G. Q., Ho, M., Drew, D. S., Chan, A. P. C. (2009) "Exploring critical success factors for stakeholder management in construction projects", Journal of Civil Engineering and Management, 15(4), pp. 337-348 https://doi.org/10.3846/1392-3730.2009.15.337-348

Yang, J., Shen, G. Q., Ho, M., Drew, D. S., Xue, X. (2011) "Stakeholder management in construction: An empirical study to address research gaps in previous studies", International Journal of Project Management, 29(7), pp. 900-910. https://doi.org/10.1016/j.ijproman.2010.07.013

Yang, R. J., Wang, Y., Jin, X.-H. (2014) "Stakeholders' Attributes, Behaviors, and Decision-Making Strategies in Construction Projects: Importance and Correlations in Practice", Project Management Journal, 45(3), pp. 74-90 https://oi.org/10.1002/pmj.21412

Yeung, A. K. O., Brockbank, J. W., Ulrich, D. (1991) "Organizational culture and human resource practices: An empirical assessment", In: Woodman, R. W., Pasmore, W. A. (eds.) Research in organizational change and development, Vol. 5., JAI Press, Greenwich, CT, USA, pp. 59-82.

Young, T. L. (2010) "Successful project management", 3rd ed., Kogan Page, London, UK, Philadelphia, PA, USA.

Zu, X., Robbins, T. L., Fredendall, L. D. (2010) "Mapping the critical links between organizational culture and TQM/Six Sigma practices", International Journal of Production Economics, 123(1), pp. 86-106.

https://doi.org/10.1016/j.ijpe.2009.07.009 